\title{
Chemical characterization of local "Beldi"almond oil for food and cosmetic purposes in northeastern of Morocco
}

\author{
Reda Melhaoui ${ }^{*}$, Souhayla Kodad $^{1}$, Nadia Houmy ${ }^{1}$, Kamal Belhaj ${ }^{2}$, Farid Mansouri ${ }^{1}$, \\ Malika Abid ${ }^{1}$, MohamedAddi ${ }^{1}$, Aatika Mihamou ${ }^{1}$, Hana Serghini Caid, ${ }^{1}$ Ahmed \\ Elamrani ${ }^{1}$ \\ ${ }^{1}$ Laboratoire d'Amélioration des Productions Agricoles, Biotechnologie et Environnement, \\ (LAPABE), Faculté des sciences, Université Mohammed Premier, Oujda, Maroc. \\ ${ }^{2}$ Laboratoire de Management de l'Agriculture Durable, EST Sidi Bennour, Université Chouaib \\ Doukkali, El Jadida, Maroc
}

\begin{abstract}
The new trend of almond planting intensification aims for better profitability at the expense of biodiversity, which will lead to forsaking of local Beldiecotypes. Indeed, European late-flowering cultivars, especially Ferragnes and Ferraduel, were recently largely planted in northeastern Morocco. In parallel with our studies on these new almond crops, which are profitable in favorable areas, this research aims to conserve local almond biodiversity. Thus, it seeks added value for products from Beldialmonds, particularly for defective kernels (Doubles, malformed, split, and broken almonds). Therefore, these defective kernels could be used as raw materials for almond oil extraction to be used in cosmetology or even in food industry. in addition, this study is the first that has been conducted to determine the characterization of the Beldi ecotype has been carried out in this region. Low acidity and peroxide indexes values, which are respectively $0.44 \%$ and $2.67 \mathrm{meq} \mathrm{O} 2 / \mathrm{Kg}$, and a medium oxidative stability value (19 hours)were recorded for the studied almond oils obtained from seeds by mechanical pressing extraction. Total tocopherols content showed significant values $528.28 \mathrm{mg} / \mathrm{Kg}$, with $\alpha$-tocopherol as dominant. The total phenolic content of the analyzed Beldi almond oil is $147.59 \mathrm{mg} / \mathrm{kg}$, The analyzed fatty acid profiles show that their composition is mainly constituted by oleic acid (64.68\%). Finally, it should be noted that despite its low production, the Beldiecotypes will continue to spread in the marginal agro-ecological zones due to their remarkable resistance to drought and their almond oils highly valued in cosmetic, especially for skin and hair care products.
\end{abstract}

\section{Introduction}

*Corresponding author:reda_melhaoui@hotmail.fr 
Sweet almonds are edible nuts of Prunus amygdalus, (var. dulcis), belonging to the Rosaceae family [1], approximately $80 \%$ of the global almond cultivated area is concentrated in California and the Mediterranean region[2]. The majority of almond cultivars are self-incompatible and must be cross-pollinated, at least two independent genes expressed in the pistil or pollen control the self-incompatibility that explains the high polymorphism of almond cultivars[3,4], and the necessity to safeguard this biodiversity. The almond tree is a typically Mediterranean crop, with large economic importance. It is able to withstand the high temperatures during the summer and the intense winter cold. It can survive long periods of drought and be cultivated on very poor land and marginal areas [5].The Almonds have numerous nutritional advantages and potential health benefits, they are considered excellent sources of energy, fats, proteins, minerals, carbohydrates, unsaturated fatty acids, phenoliccompounds and tocopherols[6-9]. In addition, the oil that is the main constituent of almond kernels, which is largely used in cosmetic especially for skinand hair care.

Currently, Morocco is the sixth-largest producer of almond nutsin the world, with an average production of 102.185 tons in 2019[2].In marginal areas, in addition to the varieties of almonds commonly cultivated, the Beldi almond trees represent a set of local almond ecotypes reflecting the richness of biodiversity and showing high adaptation to diverse edaphoclimatic conditions of the different agro-ecological areas of Morocco. However, the early pre-flowering and a relative sensitivity to late frosts, which sometimes occur in February, could be limiting factors that could affect the flowering of these almond ecotypes and therefore affect their fruit production. [10].

The resulting variability from seedling leads to high levels of heterozygosity, and therefore to a strong heterogeneity of the fruits showingpoor pomological quality (kernels of different shapes and sizes, high rate of doubles and defective kernels. However, based on the chemical analysis, Beldialmonds show excellent quality in terms of nutritional values and health benefits [11].

In Morocco, more than $50 \%$ of almond plantations are located in the regions of TazaTaounate-Alhouceima and Sous-Massa-Daraa that represent $30 \%$ of national production. However, the Saïss region produces as much with only $6 \%$ of plantations; this is due to the more intensive nature of its plantations, the availability of water, use of high-yield varieties. Indeed, the production is highly variable due to drought and the incidence of frost, which affect flowering and subsequent fruit set. Therefore, in eastern Morocco, the latest almond planting program aimed at increasingfarmer's profitability at the expense of biodiversity. This results in the introduction of new late-flowering European varieties, mainly Ferragnes and Ferraduel, which in the short term seem better adapted and more profitable but in the long term this could lead to the abandonment of the Beldi ecotypes and a loss of biodiversity.

Beldialmond kernels, showing defects in shape, size, and kernel development, unfit for human consumption, are used as raw material for almond oil extraction. This is a valuation operation for creating adding value to farm products made fromBeldialmonds and so for sustainable agriculture. This is a real opportunity for the small farmers from these marginal zones which constitutes a financial resource at the service of rural development and therefore to promote the cultivation of biodiversity preservation of theBeldialmond. Thus, our study concerns the chemical analysis of the oil extracted from Beldialmonds as a high benefit product for food and cosmetic uses.In Morocco, some studies have been conducted to determine the characterization of oil content and quality indices for almond cultivars [12-14]. however, no specific study is done on the Beldi ecotype except for preliminary work byNadia et al and Kodad et al $[11,15]$ 


\section{Material and methods}

\subsection{Almonds' harvesting and oil extraction}

Harvesting of Beldialmonds was carried in crop year 2018 out on the southern side of the Tafoghaltmountains in northeastern of Moroccoknown as ancestral areafor traditional cultivation of Beldialmond trees. This area shows great biodiversity within the same field, where plantations were done by seed germination. Thus, Almonds nuts of Beldiecotype were harvested in August at the last phase of maturity in the rural zone of Sidi Bouhria $\left(34^{\circ} 44^{\prime} 13.6^{\prime \prime} \mathrm{N}, 002^{\circ} 20^{\prime} 15.0^{\prime}\right.$ ' W). Six kilograms of shelled almonds were harvested from three almond orchards, which are mainly rain-fed but receive additional irrigation during periods of drought. Almond oil is extracted usinga mechanical oil screw press, at the speed of 70 RPM, oil's fine particles were removed by centrifugation at 3000 RPM for $15 \mathrm{~min}$. Finally, the obtained almond oil samples were stored for further analysis in the dark at a temperature of $4^{\circ} \mathrm{C}$.

\subsection{Analytical methods}

The chemical quality parameters of Beldi almond oil were analyzed, its oxidation stability was tested, and its fatty acid and triacylglycerol profiles were determined. Each parameter is analyzed in triplicate

\subsubsection{Chemical parameters and oxidative stability of Beldialmond oil}

Almond oil acidity ( $\%$ oleic acid) and peroxide value (meq $\mathrm{O}_{2} / \mathrm{Kg}$ ),

The official European methods[16] used to determine the oil acidity (\% oleic acid) and peroxide index (meq $\mathrm{O}_{2} / \mathrm{Kg}$ ) of olive oil were maintained for the evaluation of the studied almond oil (AO) quality. $3 \mathrm{~g}$ of almond oil heated at $100^{\circ} \mathrm{C}$ with an airflow of $15 \mathrm{~L} / \mathrm{h}$, was used to determine the oxidative stability index (OSI) using a MetrohmRancimat 743 apparatus[17].OSI value is expressed as the oxidation induction time (hours).

\subsubsection{Phenol analysis}

TheFolin-Ciocalteu method described by Ollivier et al, (2004) was used for analyzing the total phenolic contents of almond oil, were the absorbance was made at $750 \mathrm{~nm}$ by using caffeic acid as a standard [18]

\subsubsection{Tocopherols analysis}

HPLC-FLD equipped with an automatic injector was used for the tocopherols profile analysis, according to the AOCS method Ce 8-89 AOCS, [16] where $\alpha, \beta$, and $\gamma$ tocopherols which are the main tocopherol isomers were separated by using an Uptisphere $120 \mathrm{~A}^{\circ} \mathrm{NH} 2$ column $(150 \mathrm{~mm} * 3 \mathrm{~mm}, 3 \mu \mathrm{m}$, Interchim, Montluçon, France), with an injection volume of $10 \mu \mathrm{L}$ and a maintained temperature at $30{ }^{\circ} \mathrm{C}$. Hexane/2-propanol $(99: 1, \mathrm{v} / \mathrm{v})$ constitute the mobile phase which was eluted in isocratic conditions at a flow rate of $1 \mathrm{~mL} / \mathrm{min}$. The tocopherols were identified and quantified by external standardization (Mixture of tocopherols: $\alpha$-tocopherol, $\beta$-tocopherols, $\gamma$-tocopherols, $\delta$ tocopherols) obtained from Sigma-Aldrich (Steinheim, Germany).

\subsubsection{Fatty acids analysis}

Fatty acid profile of almond oils was identified by a standard composed of 37 methyl esters of fatty acids. Before analysis, fatty acids were converted into fatty acid methyl esters; after 
adding $8 \mathrm{~mL}$ of hexane, the mixture was subjected to gas-chromatograph analysis using an HP 6890 series gas-chromatography system equipped with an FID detector and a capillary column (Supelco Omega wax: $30 \mathrm{~m} \times 0.25 \mathrm{~mm} \times 0.25 \mu \mathrm{m}$ ). The carrier gas was nitrogen, supplied at a flow rate of $1.7 \mathrm{ml} \mathrm{min}-1$. The initial temperature of the injector was $50^{\circ} \mathrm{C}$, it was gradually increased to $150^{\circ} \mathrm{C}$ at a rate of $30^{\circ} \mathrm{C}$ min- 1 and then at a rate of $4^{\circ} \mathrm{C}$ min- 1 up to $250{ }^{\circ} \mathrm{C}$. The injection volume was $1 \mu \mathrm{l}$ in the split-less mode. This method of analysis was described in by Mansouri \& al[19].

\subsubsection{Triacylglycerols analysis.}

Analysis of molecular species of Triacylglycerols (TAGs) was carried out using $2 \mathrm{ml}$ ofBeldialmond oil dissolved in acetone (9\%) and filtered through $0.45 \mu \mathrm{m}$ membranes. TAGs profile was determined by high-performance liquid chromatography (HPLC) coupled with a refractive index detector. The column used is type $\mathrm{C} 18$ reversed-phase column (ODS C18: $250 \times 5 \mathrm{~mm}, 5 \mu \mathrm{m})$, and the mobile phase consisted of acetone/acetonitrile $(60 \%$ $-40 \%, \mathrm{v} / \mathrm{v}$ ). Elution was conducted in isocratic conditions out at $1 \mathrm{ml} / \mathrm{min}$. TAGs peaks were identified by comparison with standards triglyceride (Sigma chemical products).

\section{Results and discussion}

\subsection{Quality indexes, phenol and tocopherol ofBeldialmond oil}

Lipolysis and lipid oxidation,which causes undesired flavors and smells, are the main reasonsfor virgin almondoils spoilage,hence the importance of measuring the acidity, peroxide index, and oxidative stability index (OSI) values[20]. Those parameters are essential factors to determine the shelf-life and acceptability of almond oil via the determination of enzymatic or chemical hydrolysis of acylglycerols, as well as the secondary oxidation products such as ketones, aldehydes [21]. In this regard, the analysis resultsof physico-chemical characteristics shows a low acidity $(0.43 \%)$, a low peroxide value $\left(2.67 \mathrm{meq} \mathrm{O}_{2} / \mathrm{kg}\right.$ ) and a medium OSI value (19 hours)expressed as the oxidation induction time (Table1)

Like all vegetable oils, the presence of natural antioxidants (phenols and tocopherols) in almond oil improves its stability, and therefore its storability. Thus, phenolic compounds present in almond oil are important secondary metabolites with great antioxidant capacity. In fact, Beldialmond oil's richness of phenols delaying the oil oxidation speed by different actions and it is closely associated with the nutritional quality and health benefits. These natural antioxidantsplay a prominent role in the prevention of various diseases[22]. The total phenolic contentof the analyzed Beldialmond oil is $147.59 \mathrm{mg} / \mathrm{kg}$, (Table 1). This observed value is higher than that recorded for oils extracted from almond varieties (Ferragnes, Ferraduel, andMarcona) commonly cultivated in Morocco, which varied from $18.53 \mathrm{mg} / \mathrm{kg}$ to $237 \mathrm{mg} / \mathrm{kg}[23,24]$. This variability iscertainly attributed to the genotype and the agro-climatic conditions but also to the oil extraction methods.

In addition to their richness of phenols, almond oil is a good dietary source of tocopherols, which constitute a large class of fat-soluble compounds with vitamin E activities. In fact, vitamin $\mathrm{E}$ is a mixture of different forms of tocopherols and tocotrienols, with $\alpha$-tocopherol being the most effective form of vitamin E[25]. Due to its high content of antioxidants, almond oil may help reduce the risk of cardiovascular disease and plays an important role in preventing diseases associated with aging and protecting cell membranes from oxidative damages[26,27]. Therefore, almond oil is a natural cosmetic product that helps soothe the skin from irritation, protects from UV damage, and restores the skin's moisture barrier[28] 
Beldialmond oil was analyzed for their quantitative and qualitative tocopherol contents by HPLC-FLD. Total tocopherols content and proportion of each homolog $(\alpha-, \beta-$, and $\gamma$ tocopherols) are summarized in Table 1. Beldialmond oil has a high content of tocopherols estimated at $528.28 \mathrm{mg} / \mathrm{kg}$, with $\alpha$ tocopherol as the major homolog $(516.33 \mathrm{mg} / \mathrm{kg})$ followed by $\gamma$-tocopherol $(9 \mathrm{mg} / \mathrm{kg})$ and $\beta$-tocopherol $(2.95 \mathrm{mg} / \mathrm{kg})$. This oil is very rich in tocopherols $(528.28 \mathrm{mg} / \mathrm{kg})$ compared to that from Ferragnes and Ferraduel cultivarswhere tocopherol contents range between $(385-433 \mathrm{mg} / \mathrm{kg})[13,29]$. This high content of tocopherols a (particularly $\alpha$-homologue, the most effective form of vitamin E), make this oil a product of nutritional interest and beneficial for human health. Actually, this oilis considered an excellent source of natural antioxidants for food and cosmetic purposes. Therefore, these benefits will encourage the extension of Beldialmond cultivation for oil production. Besides this will help farmers' improving incomes, contribute to rural development, and led to protect the biodiversity of almond trees in marginal areas.

Table 1:Quality indexes, phenols and tocopherol contents in analyzedBeldialmond oil

\begin{tabular}{|c|c|}
\hline Physicochemical parameters & values \\
\hline Free acidity $(\% \mathrm{C} 18: 1)$ & $0.43 \pm 0.1$ \\
\hline peroxide value $\left(\mathrm{meqO}_{2} / \mathrm{kg}\right)$ & $2.67 \pm 0.05$ \\
\hline Total phenols $(\mathrm{mg} / \mathrm{Kg})$ & $147.59 \pm 14.50$ \\
\hline$\alpha$-tocopherol $(\mathrm{mg} / \mathrm{Kg})$ & $516.33 \pm 14.01$ \\
\hline$\beta$-tocopherol $(\mathrm{mg} / \mathrm{Kg})$ & $2.95 \pm 0.25$ \\
\hline$\gamma$-tocopherol $(\mathrm{mg} / \mathrm{Kg})$ & $9.00 \pm 1.50$ \\
\hline total tocopherol $(\mathrm{mg} / \mathrm{Kg})$ & $528.28 \pm 15.26$ \\
\hline oxidative stability index (hours) & $19.08 \pm 0.1$ \\
\hline
\end{tabular}

The oxidative stability of almond oil should be understood as the oil's sensitivity to lipid oxidation, which leads to unwanted flavors and odors. It could be affected by the storage conditions of the oil, namely light, temperature, and exposure to oxygen, but also by its content of natural antioxidants. It is, therefore, necessary to measure the OSI of Beldialmond oil, which is a key parameter that refers to the susceptibility of the oil to lipid oxidation and which provides information about oil quality and its aptitude for storage [33].The result of the analyzed Beldialmond oil showed an OSI value of $19.08 \mathrm{~h}$, which's comparable to those of literature that range from 10.2 to $24.2 \mathrm{~h}[23,34]$. The richness in antioxidants of Beldialmond oil would explain its resistance to oxidation and therefore its good stability during storage

by comparing these results with other type of vegetable oil such as olive oil, the latter presents high phenol values with $316.59 \mathrm{mg} / \mathrm{kg}$ and SOI with $44.55 \mathrm{~h}$ for the picholine ecotype. For tocopherol olive oil has less tocopherol concentration with $254.13 \mathrm{mg} / \mathrm{Kg}$ [30]. regarding of oil characteristics of non-industrial hemp (Cannabis sativa L.), the total tocopherol content was between 376.46 and $796.06 \mathrm{mg} \mathrm{kg}^{-1}$ of oil, with a dominance of $\gamma$ tocopherol [31], which is not the case for almond oil with a dominance of $\alpha$ - tocopherol. for argan oil, the total phenolic content was lower than $10 \mathrm{mg} / \mathrm{Kg}$. the total tocopherol content range between $(383-485 \mathrm{mg} / \mathrm{Kg})$, the oils from unroasted seeds presented same stability of almond oil with value ranged between $16 \mathrm{~h}$ and $32 \mathrm{~h}$ [32] 


\subsection{Fatty acids and triacylglycerols profiles}

The fatty acidsare classified into three groups, including saturated fatty acid (SFA), monounsaturated fatty acid (MUFA), and polyunsaturated fatty acid (PUFA). They plays multiple roles in human's health and other organisms[35]. The content of saturated fatty acids in Beldialmonds oil is very low $(10.03 \%)$ while the proportion of unsaturated FA (UFA= MUFA+ PUFA) is very important (89.89\%). The most important unsaturated fatty acids are oleic acid and linoleic acid, the contents of which are estimated at $64.68 \%$ and $24.37 \%$ respectively. Table 2 presents the Beldialmond oil fatty acids profile, the mean values of SFA, MUFA, PUFA, and the ratios UFA/SFA and O/L. Among the eleven fatty acids identified, four of them are major and which are respectively in order of quantitative importanceC18:1 (64.68\%), C18:2 (24.37\%), and C16:0 (7.22\%),C18:0 (2.62\%). The GCFIDanalysis allows the detection and identification of seven other fatty acidsin the form of traces, As stated by several studies that refer to the benefits of unsaturated FA intake on risk factors for cardiovascular disease, the consumption of Beldialmond oil will provide nutritional and health benefits. in addition, its $\mathrm{O} / \mathrm{L}$ ratio (2.65) reflects its richness oleic acid (C18: 1), considered to be the healthiest FA in the diet and equally as an indicator of the good nutritional value of this oil [36].the fatty acid profile of almond oil is comparable to that of olive oil and argan oil with higher values of oleic acid $75.68 \%$ and $48.1 \%$ respectively[19,37], but it is different compared to non-industrial hemp oil (Cannabis sativa L.) with a predominance of linoleic acid $(48.26 \%-55.39 \%)[31]$.

The HPLC analysis of triacylglycerols (TAGs) of Beldialmond oil allows the identification of eleven molecular species; four of them are major ones (OOO, OOL, LLO and POO) covering together more than $83 \%$ of total TAGs. The other eight TAGS are minors triacylglycerols (LLL, LPL, SOO, LLS+ POL, POP, SLO, and, PPL, together they represent less than $20 \%$ of the total TAGs, Where $\mathrm{P}$ is palmitic acid, $\mathrm{O}$ is oleic acid, $\mathrm{S}$ is stearic acid and $\mathrm{L}$ is linoleic acid (Figure 1).

Table2: Fatty acids (FA)profile of Beldialmond oil (SFA: Saturated FA; UFA Unsaturated FA: MUFA: Monounsaturated FA; PUFA: Polyunsaturated FA, $\mathrm{O} / \mathrm{L}=$ Oleic/ Linoleic ratio

\begin{tabular}{|c|c|}
\hline Fatty acids (\%) & Mean \pm Standard deviation \\
\hline C14:0 & $0.04 \pm 0.01$ \\
\hline C16:0 & $7.23 \pm 1.00$ \\
\hline C16:1 & $0.65 \pm 0.20$ \\
\hline C17:0 & $0.06 \pm 0.02$ \\
\hline C17:1 & $0.09 \pm 0.01$ \\
\hline C18:0 & $2.62 \pm 0.59$ \\
\hline C18:1 & $64.68 \pm 4.00$ \\
\hline C18:2 & $24.37 \pm 3.00$ \\
\hline C18:3 & $0.04 \pm 0.01$ \\
\hline C20:0 & $0.08 \pm 0.02$ \\
\hline C20:1 & $0.06 \pm 0.02$ \\
\hline
\end{tabular}




\begin{tabular}{|c|c|}
\hline SFA & $10.03 \pm 1.63$ \\
\hline MUFA & $65.48 \pm 4.23$ \\
\hline PUFA & $24.41 \pm 3.02$ \\
\hline UFA/SFA & $8.96 \pm 0.64$ \\
\hline O/L & $2.65 \pm 0.13$ \\
\hline
\end{tabular}

The analyzed Beldialmond oil presents two main predominant TAGs, OOO (37.87\%) and OOL (23.47\%) which in total represent more than $60 \%$ of total TAGs. This is in perfect agreement with its richness in oleic acid (64.68\%).

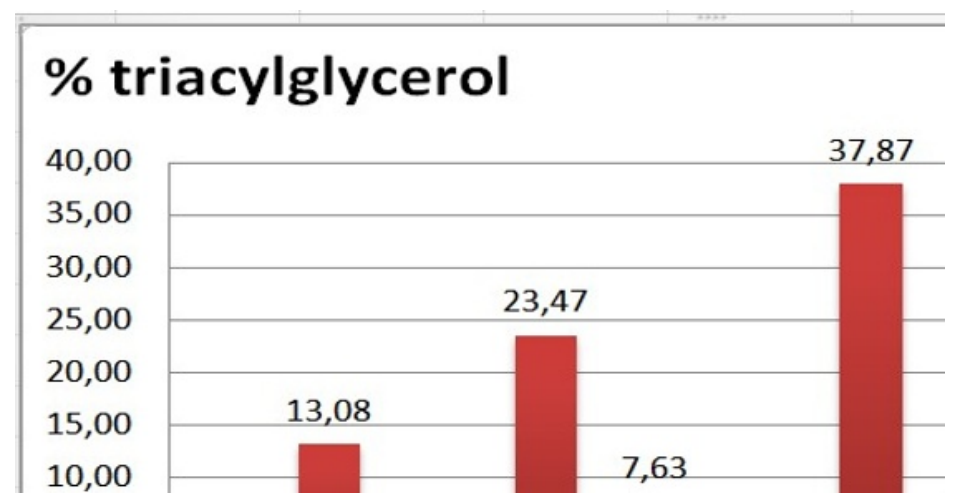

Figure 1: Profile of triacylglycerols (TAGs) of almond oil extracted from defective kernels of almonds Beldiecotype. (Eleven TAGs species were identified, OOO, OOL, LLO and POO as majors ones, LLL, LPL, SOO, LLS+ POL, POP, SLO, PPL as minors and where O $=$ oleic acid, $\mathrm{L}=$ linoleic acid, $\mathrm{P}=$ palmitic acid and $\mathrm{S}=$ stearic acid.

\section{Conclusion}

This work is the first assessment of the quality of Beldialmond oil produced in a rural cooperative located in eastern Morocco. The study concerns the use of defective Beldialmonds (small, split and broken, and malformed kernels) as raw material for the extraction of almond oil by mechanical pressing of defective kernels unfit for human consumption. As shown by chemical analyzes, Beldialmond oil has the required biochemical qualities which make it a product of interesting nutritional quality as edible oil. In addition, its richness in tocopherols and other bioactive molecules gives it other beneficial properties for its cosmetic use. Thus, both for food use but especially for cosmetic applications Beldialmond oil extracted from defective kernels is profitable. Finalybeldi almond oil generates benefits that could directly improve the small farmers' income, which therefore contributes to the preservation of this culture and its biodiversity as well. in addition to the physico-chemical characterization of almond oil, it is necessary to develop an effective protocol for clonal propagation of interesting "Beldi" almond genotypes carrying the desired agronomic traits

\section{Acknowledgments}

The Moroccan Ministry of High Education and Research supported this work. The authors are indebted to the "Centre National de Recherche Scientifique et Technique (CNRST), they also gratefully acknowledge the financial participation from the "programme de recherché appliquée(PARAI) 


\section{References}

1. Chin S-W, Shaw J, Haberle R, Wen J and Potter D. Mol Phylogenet Evol76: 34-48 (2014)

2. FAO-Stat. FAO-Stat. 2020. Crops. Items: Almond with Shell. Year: (2019)

3. Gómez EM, Dicenta F, Batlle I, Romero A and Ortega E. Scientia Horticulturae245: 218-223 (2019)

4. Tao R and Iezzoni AF. Scientia Horticulturae124: 423-433 (2010)

5. Abdini A, Imani A, Rasouli M, Zinalabdini M and Abdoosi V. Journal of Nuts11: 7390 (2020)

6. Altamimi M, Zidan S and Badrasawi M. Nutr. Metab. Insights13, (2020)

7. Liu Y, Hwang H-J, Ryu H, Lee Y-S, Kim H-S and Park H. Nutr. Res. Pract.; 11: 479486 (2017)

8. García MC, González-García E, Vásquez-Villanueva R and Marina ML. Food Funct.7: 4693-4701 (2016)

9. Ojeda-Amador RM, Fregapane G and Salvador MD. European Journal of Lipid Science and Technology121: 1900114 (2019)

10. Parker L, Pathak T and Ostoja S. Science of The Total Environment762: 14 (2021)

11. Kodad O, Estopañán G, Juan T and Socias i Company R. Journal of Food Composition and Analysis33: 161-165 (2014)

12. Sakar EH, El Yamani M and Rharrabti Y. J Mater Environ Sci8: 2679-2686 (2017)

13. Melhaoui R, Fauconnier M-L, Sindic M, Addi M, Abid M, Mihamou A, SerghiniCaid H and Elamrani A. Comm. Appl. Biol. Sci, Ghent University, 83/1(2018)

14. Melhaoui R, Houmy N, Kodad S, Belhaj K, Mansouri F, Addi M, Abid M, Mihamou A, Hano C, Sindic M, C HS and Elamrani A. E3S Web Conf.240: 04004 (2021)

15. Houmy N, Mansouri F, Benmoumen A, Elmouden S, Boujnah M, Sindic M, Fauconnier M-L, Serghini-Caid $\mathrm{H}$ and Elamrani A. Cahiers Options Méditerranéennes(2015)

16. AOCS. Determination of Tocopherols and Tocotrienols in Vegetable Oils and Fats by HPLC. Offic. Method (Ce 8-89).; (1989)

17. Mansouri F, Ben Moumen A, Lopez G, Fauconnier M-L, Sindic M, Serghini-Caid H and Elamrani A. In Book of Proceedings InsideFood Symposium 6 (2013)

18. Ollivier D, Boubault E, Pinatel C, Souillol S, Guérère M and Artaud J. In Annal Expert Forum Chem Toxicol. Vol 965169-196 (2004)

19. Mansouri F, Benmoumen A, Richard G, Fauconnier M-L, Sindic M, Serghini-Caid H and Elamrani A. Rivista Italiana Sostanze Grasse93: 21-30 (2016)

20. Roncero JM, Álvarez-Ortí M, Pardo-Giménez A, Gómez R, Rabadán A and Pardo JE. Rivista Italiana delle Sostanze Grasse93: 237-243 (2016)

21. Baltazar P, Hernández-Sánchez N, Diezma B and Lleó L. Agronomy 2020; 10: 41.

22. Alu'datt MH, Rababah T, Alhamad MN, Al-Mahasneh MA, Almajwal A, Gammoh S, Ereifej K, Johargy A and Alli I. Food Chemistry218: 99-106 (2017)

23. Rabadán A, Álvarez-Ortí M, Gómez R, Miguel C de and Pardo JE. Journal of the Science of Food and Agriculture98: 2402-2410 (2018)

24. Ozcan MM, Matthaeus B, Aljuhaimi F, Ahmed IAM, Ghafoor K, Babiker EE, Osman MA, Gassem MA and Alqah HAS. J. Food Sci. Technol.-Mysore57: 4182-4192 (2020)

25. Combs Jr GF and McClung JP. The Vitamins: Fundamental Aspects in Nutrition and Health. Academic press; (2016)

26. Tungmunnithum D, Elamrani A, Abid M, Drouet S, Kiani R, Garros L, Kabra A, Addi M and Hano C. Applied Sciences 10: 3313 (2020)

27. Chen B, McClements DJ and Decker EA. Critical Reviews in Food Science and Nutrition51: 901-916 (2011)

28. Lin T-K, Zhong L and Santiago JL. International journal of molecular sciences 19: 70 
(2018)

29. Kodad O, Estopanan, G, Teresa Juan, Ali Mamouni and Rafel Socias i Company. $J$ Agric Food Chem.6137-6141(2011)

30. Mansouri F, Benmoumen A, Richard G, Fauconnier M-L, Sindic M, Serghini-Caid H and Elamrani A. Rivista Italiana Sostanze Grasse93: 21-30 (2016)

31. Taaifi Y, Benmoumen A, Belhaj K, Aazza S, Abid M, Azeroual E, Elamrani A, Mansouri F and Serghini-Caid H. International Journal of Food Science \& Technology65$11(2021)$

32. Cayuela JA, Rada M, Pérez-Camino M del C, Benaissa M, Abdelaziz E and Guinda Á. European Journal of Lipid Science and Technology110: 1159-1166 (2008)

33. Rabadán A, Álvarez-Ortí M, Pardo JE and Alvarruiz A. Food Chemistry259: 31-35 (2018)

34. Kochhar SP and Henry CJK. International Journal of Food Sciences and Nutrition60: 289-296 (2009)

35. Sales-Campos H, Reis de Souza P, Crema Peghini B, Santana da Silva J and Ribeiro Cardoso C. Mini reviews in medicinal chemistry13: 201-210 (2013)

36. Čolić SD, Fotirić Akšić MM, Lazarević KB, Zec GN, Gašić UM, Dabić Zagorac DČ and Natić MM. Food Chemistry234: 455-463 (2017)

37. Rueda A, Seiquer I, Olalla M, Giménez R, Lara L and Cabrera-Vique C. Journal of Chemistry(2014) 